\title{
BUSINESS EFFICIENCY AND BUSINESS PERFORMANCE OF COCONUT SUGAR SMES IN BANYUMAS REGENCY
}

\author{
Lilis Siti Badriah ${ }^{1}$, Arintoko $^{2}$, Dijan Rahajuni ${ }^{3}$ \\ 1lilis.badriah@unsoed.ac.id \\ Jenderal Soedirman University \\ J1. Profesor DR. HR Boenyamin No.708, Banyumas, Jawa Tengah 53122
}

received: 6/9/21; revised: 28/10/21; approved: 20/12/21

\begin{abstract}
This study aims to analyze economic efficiency and the factors that influence the performance of coconut sugar SMEs in Cilongok District, Banyumas Regency. This study uses primary data obtained through interviews with 162 respondents. By using Benefit-Cost Ratio analysis and multiple regression, this study finds that the coconut sugar business in Cilongok District, Banyumas Regency is not yet efficient and the coconut sugar business performance is positively influenced by financial capital. While social capital and human capital do not affect it. This research implies the need for continuous efforts from all stakeholders to provide business assistance and certainty in product marketing so that product prices become more stable. In addition, it is also necessary to optimize the potential of social and human capital to strengthen the role of financial capital in improving business performance. This can be done through the institutionalization of social capital and optimizing the role of the village government in facilitating cooperation with various parties.
\end{abstract}

Keywords: economic efficiency; business performance; financial capital; social capital; human capital

\section{INTRODUCTION}

Micro, Small, and Medium Enterprises play an important role in the national development process, because based on data from the Ministry of Cooperatives and MSMEs, in 2019 around 99.9 percent of business units in Indonesia were MSMEs, which consisted of 60,702 medium enterprises units, 783,132 small businesses units, and 63,5 million micro-enterprises units. The contribution of MSMEs to the national GDP reached 60.34 percent, while the contribution to employment reached 97 percent of the national workforce. On a provincial level, data on MSMEs in Central Java Province in the second quarter of 2019 amounted to 151,968 units. The number of MSMEs tends to increase from 2008-2019 with an average growth of 8.22 percent per year. The increasing number of MSMEs also has an impact on increasing employment, with an average of 14.95 percent per year (Cooperative Service, Small and Medium Enterprises Central Java Province, 2019).

Likewise, the conditions that occur in Banyumas Regency. Based on data from the Banyumas Regency Manpower, Cooperative, and SMEs Office, in 2018 there were 84,350 MSMEs units capable of absorbing 127,534 workers. Although the contribution of MSMEs in employment is quite large, it has not had a significant impact on poverty reduction in Banyumas Regency. This can be seen from BPS (2020), during 2018-2019 the average proportion of poor people in Banyumas per year is 13.02 percent, higher than the Central Java province in the same year which is average of 11.06 percent. This is due to the low performance/productivity of MSMEs in Banyumas Regency.

One of the MSMEs that produces featured products in Banyumas Regency is the coconut sugar business. Based on BPS (2020), coconut sugar production in Banyumas Regency in 2018 amounted to 67,340 tons and rose to $68,806.3$ tons in 2019. The amount of coconut production mostly is deres coconut (coconut as a source of sap as raw material for coconut sugar). Deres coconut production in Banyumas Regency in 2018 was 53,408.86 tons, increasing to 54,995.38 tons in 2019. The largest production of coconut was in Cilongok District, in 2018 it was 10,736.2 tons, increasing to 10,929.2 tons in 2019. Therefore, it can be understood that the coconut sugar center in Banyumas Regency is in Cilongok District.

Based on data from the Department of Manpower, Cooperatives, and SMEs of Banyumas Regency, it can be seen that from 20 villages in Cilongok District, there are five villages with the largest number of coconut sugar 
MSMEs, namely Langgongsari Village (427 units), Sudimara (414 units), Batuanten (329 units), Rancamaya (239 units), and Kasegeran (196 units). Optimal development of MSMEs based on local resource potential has the opportunity to have high competitiveness considering that the availability of raw materials in Cilongok District is quite large. The existence of this coconut sugar business can be a source of revenue for the original income of the village and the original income of Banyumas Regency and can be a source of employment. If this is to be developed optimally, the existence of a coconut sugar business should be able to become an engine of economic growth for the region in reducing unemployment and poverty. However, the existing phenomenon shows that in 2018, the percentage of poor people in Cilongok District is relatively high, namely 17.49 percent, higher than the poverty rate of Banyumas Regency in the same year which is 13.50 percent (BPS, 2019). This indicates that the performance of the coconut sugar business in the Cilongok District is relatively low.

Several previous studies have shown that several factors can affect the performance of MSMEs, including capital deepening and human capital (Badriah et al, 2019) and social capital (Prakasa, 2018; Nee et al, 2017; Hoq et al, 2017; Dai et al, 2015; Felício et al, 2014).

Bourdieu (1980) in Kuncoro (2010) defines social capital as an aggregate of actual and potential resources that are bound to create networking to institutionalize mutually beneficial friendly relations. According to Kuncoro, social networks are formed through an investment strategy oriented towards the institutionalization of group relations that can be used as a reliable source of profit. Thus, there are 2 elements of social capital, namely social relationships that allow individuals to access resources owned by their associations, and the amount/ quality of these resources. This is in line with Putnam (1995) which states that social capital is a description of social organization, such as networks, norms, and social trust that facilitate mutually beneficial coordination and cooperation. The smooth and successful achievement of organizational goals, including business organizations, cannot be separated from the availability of capital owned, both in the form of economic capital (financial capital), human capital, and social capital. In contrast to other capital, the existence of social capital will be seen when it interacts with the social structure (Kuncoro, 2010).

The existence of social capital is very important in supporting the optimization of human capital and financial capital of MSMEs to improve business performance. This is in line with the results of research by Badriah et al (2019) that capital deepening and human capital affect increasing labor productivity growth in the industrial sector.

One of the indicators of business performance is the ability of MSMEs to create economic efficiency. According to Nicholson \& Snyder (2010), economic efficiency indicates a condition that is technically efficient in the production process and the products produced are under consumer preferences in the market. This means that such conditions can provide greater revenue than the costs. A business with good performance will have greater revenue than the cost. That is, the company can create income greater than costs, causing the company to be feasible to continue to be developed. Many factors can affect efficiency. This is shown in Kurniati \& Prajanti (2018) that the role of entrepreneurs in product innovation, marketing innovation, and business alliances is an important factor that can affect the efficiency of Batik SMEs in Solo, Pekalongan, and Rembang. Marketing innovation is the factor with the greatest elasticity to the production and sales of Batik. Thus, this research supports the importance of the role of social capital, human capital, and financial capital in encouraging the success of a business, especially MSMEs.

Based on the background described above, this study aims to analyze economic efficiency and the effect of social capital, human capital, and financial capital on the performance of Coconut Sugar SMEs in Cilongok District, Banyumas Regency. In contrast to previous studies, this study combines the variables of social capital, human capital, and financial capital in an analysis related to their effect on SMEs' performance.

This research can provide policy recommendations related to the optimization of social capital, human capital, and financial capital in the development of MSMEs to improve the performance of the coconut sugar business in the Banyumas Regency. This is important considering that the raw material for coconut sugar available in Banyumas Regency is very abundant. This condition is expected to provide a comparative advantage and competitive advantage that can encourage the improvement of the economy of Banyumas Regency as a whole so that in the end it can improve the welfare of the community. By the increase in the performance of coconut sugar MSMEs, it is expected to reduce the level of poverty in Banyumas Regency where is in line with one of the objectives of the Sustainability Development Goals (SDGs) program.

\section{METHODS}

The research was conducted in Cilongok District, Banyumas Regency, with a population of Coconut Sugar MSMEs. The sampling method used purposive sampling: (1). selected sub-districts with the highest number of coconut sugar MSMEs (Cilongok), (2) from the selected sub-districts, 5 villages with the highest number of 
Coconut Sugar MSMEs were selected (Langgongsari, Sudimara, Batuanten, Rancamaya, and Kasegeran), (3) from each selected village taken $10 \%$ of MSMEs coconut sugar as respondents. Based on the determination of the sample, the number of respondents who are representative of the entire population in the 5 selected villages is 180 respondents.

The analytical methods used in this study are: (1) for the analysis of business efficiency using the BenefitCost Ratio approach with the following formula:

$$
\mathrm{B} / \mathrm{C}_{\text {ratio }}=\text { Total Revenue } / \text { Total Cost }
$$

If the $B / C_{\text {ratio }}>1$ indicates that the coconut sugar business is efficient if the $B / C_{\text {ratio }}=1$ indicates that the coconut sugar business has reached the break-even point, and if the $\mathrm{B} / \mathrm{C}_{\text {ratio }}<1$ indicates that the coconut sugar business is not efficient (Soekartawi, 2006). (2) for the analysis of the effect of social capital, human capital, and financial capital on the performance of Coconut Sugar SMEs using multiple regression analysis methods with the following formula:

$$
\ln Y_{\mathrm{i}}=\beta_{0}+\beta_{1} \mathrm{X}_{1 \mathrm{i}}+\beta_{2} \ln \mathrm{X}_{2 \mathrm{i}}+\beta_{3} \ln \mathrm{X}_{3 \mathrm{i}}+\varepsilon_{\mathrm{i}}
$$

Information:

$\mathrm{Y}=$ Performance of coconut sugar SMEs (with a variable indicator in the form of income of coconut sugar craftsmen per month as measured by Rp/month)

$\mathrm{X}_{1}=$ Social capital (with variable indicators in the form of norms, trust, networking, as measured by a Likertscale)

$\mathrm{X}_{2}=$ Human capital (with a variable indicator in the form of work experience as measured by years)

$\mathrm{X}_{3}=$ Financial capital (with a variable indicator in the form of capital per month as measured by $\mathrm{Rp} / \mathrm{month}$ )

\section{RESULTS}

Total revenue is calculated by multiplying the total production $(\mathrm{Q})$ and selling price $(\mathrm{P})$. The coconut sugar production process in Cilongok District is carried out every day. The amount of production of each coconut sugar craftsman varies depending on the amount of raw material (sap) obtained which is also determined by the number of coconut trees that are cultivated by coconut sugar craftsmen. The coconut sugar business in Cilongok District is generally carried out on a small business scale. In running a business, a coconut sugar craftsman does the entire work process by himself, so a coconut sugar craftsman is also the owner of the coconut sugar business. The number of coconut trees that are cultivated by coconut sugar craftsmen can be seen in Table 1.

Table 1. Respondents Based On The Number of Coconut Trees Harvested

\begin{tabular}{cc}
\hline Number of coconut trees & Number of Respondents (Persons) \\
\hline $2-6$ & 5 \\
$7-11$ & 18 \\
$12-16$ & 31 \\
$17-21$ & 46 \\
$22-26$ & 39 \\
$27-31$ & 24 \\
$32-36$ & 4 \\
$37-41$ & 13 \\
\hline Jumlah & 180 \\
\hline
\end{tabular}

Based on the data in Table 1, it can be seen that the majority of respondents (46 people) take coconut sap from 17-21 coconut trees per day. As for the ownership of the coconut tree which the sap was taken by coconut sugar craftsmen, not all of them are owned by themselves, but some are using a mixed system. Based on the data obtained, the ownership of the coconut tree which the sap was taken by coconut sugar craftsmen, can be seen in Table 2. 
Table 2. Respondents Based on Coconut Tree Ownership

\begin{tabular}{lc}
\hline \multicolumn{1}{c}{ Tree ownership } & Number of Respondents (Persons) \\
\hline Own ownership & 64 \\
Mixed Ownership: & 56 \\
Maro & 33 \\
Mendreng & 10 \\
Rent & 1 \\
Pawn & 13 \\
Mendreng and maro & 1 \\
Mendreng and rent & 1 \\
Maro, mendreng, and pawn & 1 \\
Maro and rent & 180 \\
\hline \multicolumn{2}{c}{ Total }
\end{tabular}

Based on Table 2, the ownership of coconut trees which the sap was taken by coconut sugar craftsmen, $64.44 \%$ are mixed, while $35.56 \%$ are their own. As shown in Table 2, the mixed systems also varied, with the majority of the mixtures being maro $(48.28 \%)$ and mendreng $(28.45 \%)$. In the maro system, the coconut sugar craftsmen take sap from other people's trees, then every certain time (eg 5 days) the sap that is squeezed is processed by the craftsmen into coconut sugar and then sold by themselves. Meanwhile, at other times (for example, the next 5 days) the sap that is harvested is deposited to the tree owner to be processed by themselves, and the sugar is sold by them. Whereas in the mendreng system, the coconut sugar craftsmen take sap from other people's trees, then he processes it into ready-to-eat coconut sugar, and at a certain agreed time, he must deposit a certain amount of coconut sugar to the tree owner.

The number of coconut trees cultivated by craftsmen will determine the amount of sap obtained and will then determine the amount of coconut sugar produced. Based on the data obtained, the amount of sugar produced by each craftsman varies between $1.5 \mathrm{~kg}-13 \mathrm{~kg}$ per day, with an average production of $5.4 \mathrm{~kg} /$ day. A total of 74 people $(41.11 \%)$ produce coconut sugar as much as $5.5-6.5 \mathrm{~kg} /$ day. Then 49 people $(27.22 \%)$ produced sugar as much as $3.4-4.5 \mathrm{~kg} /$ day, and 38 people $(21.11 \%$ ) produced sugar as much as $7.5-8.5 \mathrm{~kg} /$ day.

The types of sugar produced by the majority of craftsmen, namely 152 people (84.44\%), made molded coconut sugar, 25 people (13.89\%) made crystal sugar, and 3 people $(1.67 \%)$ made both types of coconut sugar. Even though the selling price of crystal sugar is higher than molded sugar, the majority of craftsmen produce molded sugar because the cost required to produce molded sugar is relatively cheaper than crystal sugar. To make crystal sugar, a craftsman needs an oven, which not all craftsmen can afford because it is relatively expensive.

The selling price of molded coconut sugar in the market is an average of Rp. 15,500/kg, while the price of crystal sugar in the market is around Rp. 25,000.00/kg. However, the majority of coconut sugar producers do not sell their sugar in the market. The selling price other than the market price is lower than the selling price in the market. The selling price of molded coconut sugar which is not sold directly to the market is an average of Rp. $13,000.00 / \mathrm{kg}$ and for crystal sugar around Rp. 19,000.00/kg. Even though the selling price outside the market is cheaper, and is considered by the craftsmen the price is unstable, but the craftsmen cannot do much because there is the dependence from the craftsmen on the buyers of the coconut sugar they produce. The craftsmen sell their sugar to collectors or stalls because these buyers have provided their services to the craftsmen, either in the form of tools assistance, assistance for production auxiliary raw materials (limestone and mangosteen peel), as well as in the form of money.

Among several coconut sugar craftsmen, some sell their sugar to collectors who already have cooperated with companies that are exporters of coconut sugar. Among them is UD Sari Manggar, which has cooperated as a supplier of wet crystal sugar for the exporter company CV. Permata Satria and some collectors have cooperated to supply wet crystal sugar for the exporting company P.T. Coco Sugar Indonesia. According to information from separate interviews with collectors who have partnered with exporting companies, as collectors who have partnerships with exporters, the purchase price of sugar from farmers who sell their sugar to them is set higher than the price prevailing in other collectors, because it determines the price selling is from the company that is the partner, and the determination of the price takes into account the market price and the price is set the same as long as the sugar craftsman is a member of the membership as a supplier for the collectors who partner with the exporter company. In addition, craftsmen who have to cooperate with collectors who partner with exporting 
companies will get product certification facilities under the required export standards. However, the number of craftsmen who cooperate with such collectors is still relatively limited compared to the total population of coconut sugar craftsmen in the Cilongok District.

Among coconut sugar craftsmen, although they produce every day, the frequency of sales of their products is relatively varied, ranging from once a day - once every 30 days. The majority of craftsmen, 105 people (58.33\%), sell their sugar production every 5-8 days. On average, coconut sugar craftsmen sell their sugar every 6 days.

The description of the coconut sugar business can contribute to the performance of the coconut sugar business, which in this case uses the monthly revenue indicator. Based on the results of calculations from survey data, the average monthly income from coconut sugar craftsmen in Cilongok District is Rp 2,521,600.00/month.

The cost components in the coconut sugar business consist of: (1) Fixed cost. Fixed costs in the coconut sugar business include all equipment and supplies needed to produce coconut sugar, such as stoves, frying pans, pongkor (a container used to hold sap water), and other supporting equipment. (2) Variable costs in the coconut sugar business include the costs of raw materials (sap, mangosteen rind, limestone), firewood, and labor.

Based on data obtained from the field, it can be seen that the coconut sugar production process is carried out every day. However, the process of selling products is not done the same, so in the calculation of this cost component, it is calculated in units of production per month. The components of fixed costs after deducting depreciation costs and the components of variable costs can be seen in Table 3.

Table 3. The Total Production Cost of Coconut Sugar Business Per Month

\begin{tabular}{cc}
\hline Cost Type & Number (Rp) \\
\hline Fixed cost & 171,166 \\
Variable cost & $9,035,833$ \\
\hline Total cost & $9,206,999$ \\
\hline Source: primary data processed, 2021
\end{tabular}

Source: primary data processed, 2021

Economic efficiency is calculated by comparing the total revenue with the total cost. The results of these calculations can be seen in Table 4.

Table 4. Calculation of Economic Efficiency of Coconut Sugar Business Per Month

\begin{tabular}{cc}
\hline Components & Number $(\mathrm{Rp})$ \\
\hline Total revenue & $2,521,600$ \\
Total cost & $9,206,999$ \\
\hline Economic efficiency & 0,27 \\
\hline
\end{tabular}

Source: primary data processed, 2021

Based on Table 4, it can be seen that the value of economic efficiency, which is reflected in the value of the ratio between total revenues and total costs, is relatively low, at 0.27 .

The performance of the coconut sugar business is seen by using an indicator of the revenue of craftsmen obtained from the coconut sugar business in one month. Based on Putnam (1995), Kurniati \& Prajanti (2018), Badriah, et al. (2019), Prakasa (2018), Nee, et al. (2017), Hoq, et al. (2017), Dai, et al. (2015), Felício, et al. (2014), there are known that the quality of social capital, the quality of human capital, and the amount of financial capital can affect the performance of SMEs.

Analysis of the influence of social capital, human capital, and financial capital on the performance of Coconut Sugar SMEs was carried out using multiple linear regression with cross-sectional data. The number of initial data used was 180 according to the number of respondents, but in the data processing process it turned out that some of the data had extreme characteristics. Therefore, these data were omitted from the analyzed data. Thus, in the end, the number of data becomes 162, with the human capital indicator $\left(\mathrm{X}_{2}\right)$ in the form of work experience. To obtain a valid estimation result, the classical assumption test must first be carried out, namely the fulfillment of the element of normality, and avoiding the symptoms of multicollinearity, heteroscedasticity, and autocorrelation.

Normality detection was carried out using Jarque-Bera (JB), and the results shown is greater than $\alpha=0.05$ so it can be stated that the data is normally distributed. All explanatory variables have a value of VIF (Centered) $<10$, so it is concluded that there is no multicollinearity in the model. Detection of the presence or absence of heteroscedasticity was carried out using the Breusch-Pagan-Godfrey Test. The results shown that the p-value of the F-Statistics is 0.9170 , so it can be said that there is no heteroscedasticity in the model used. 
The results of multiple regression calculations can be seen in Table 5 .

Table 5. Multiple Regression Calculation Results

\begin{tabular}{|c|c|c|c|c|}
\hline \multicolumn{5}{|c|}{ Dependent Variable: $\ln Y$} \\
\hline \multicolumn{5}{|c|}{ Method: Least Squares } \\
\hline \multicolumn{5}{|c|}{ Date: 07/01/21 Time: $12: 48$} \\
\hline \multicolumn{5}{|l|}{ Sample: 1162} \\
\hline \multicolumn{5}{|c|}{ Included observations: 162} \\
\hline Variable & Coefficient & Std. Error & t-Statistic & Prob. \\
\hline $\mathrm{C}$ & 10.43255 & 1.002343 & 10.40817 & 0.0000 \\
\hline $\mathrm{X}_{1}$ & -0.001782 & 0.005614 & -0.317374 & 0.7514 \\
\hline $\ln X_{2}$ & -0.115673 & 0.067451 & -1.714935 & 0.0883 \\
\hline $\ln X_{3}$ & 0.311025 & 0.061714 & 5.039773 & 0.0000 \\
\hline R-squared & 0.188153 & \multicolumn{2}{|c|}{ Mean dependent var } & 14.39474 \\
\hline Adjusted R-squared & 0.172738 & \multicolumn{2}{|c|}{ S.D. dependent var } & 0.385209 \\
\hline S.E. of regression & 0.350363 & \multicolumn{2}{|c|}{ Akaike info criterion } & 0.764686 \\
\hline Sum squared resid & 19.39513 & \multicolumn{2}{|c|}{ Schwarz criterion } & 0.840923 \\
\hline Log-likelihood & -57.93954 & \multicolumn{2}{|c|}{ Hannan-Quinn criteria. } & 0.795639 \\
\hline F-statistic & 12.20598 & \multicolumn{2}{|c|}{ Durbin-Watson stat } & 1.777521 \\
\hline Prob(F-statistic) & 0.000000 & & & \\
\hline
\end{tabular}

Source: primary data processed, 2021

Based on the data in Table 5, only the financial capital variable has a significant positive effect on the performance of the Coconut Sugar SMEs, while the social capital and human capital variables have an insignificant negative effect on the performance of SMEs. This can be seen from the indicator value of the p-value of the variable $\mathrm{X}_{3}$ (financial capital) which is smaller than the value of $=0.05$, meaning that financial capital has a significant positive effect on the performance of coconut sugar SMEs while for other variables, namely $\mathrm{X}_{1}$ (social capital) and $X_{2}$ (human capital) shows the $p$-value is greater than the value of $\alpha=0.05$, meaning that these two variables have the negative effect on the performance of coconut sugar SMEs in Cilongok District, Banyumas Regency but not significant.

\section{DISCUSSIONS}

The results of the calculation of economic efficiency using the benefit-cost ratio are shown in Table 1. Based on the table, it can be seen that the economic efficiency of the coconut sugar business is less than 1, which is 0.27 . This means that for every Rp. 1,000.00 the cost incurred in the production process can only provide revenue of Rp. 270.00. Thus it can be said that the production costs incurred are greater than the revenues obtained from the coconut sugar business. This means that the condition of the coconut sugar business in Cilongok District, Banyumas Regency is not yet efficient. This condition can be understood because most of the coconut sugar businesses have relatively small business scales so that on a relatively small scale, the ability to create business efficiency processes is relatively limited. This is in line with the results of research by Kurniati \& Prajanti (2018) which states that economies of scale make batik SMEs experience inefficiency in adopting technology, accessing infrastructure, and building business brands and the ability to pay for professionals. This is also in line with research by Muslihuddin, et al. (2020) which shows that the fishing business in Ampana District, Tojo Una-Una Regency, which is also part of SMEs, is not yet efficient.

Based on the results of multiple linear regression calculations, as shown in Table 5, the human capital variable has an insignificant negative effect on the performance of SMEs. This insignificant effect occurs because the social capital potential that exists in the coconut sugar craftsman community has not been optimized. This means that the potential for their social capital as rural communities already exists, but has not been optimized 
in their business development efforts. According to Putnam (1995) that social capital is a description of social organization, such as networks, norms, and social trust that facilitate mutually beneficial coordination and cooperation. Because in doing their business, the majority of them are still independent, no business group allows them to optimize the social capital for the benefit of their business development. Thus, the indicators of social capital obtained in this study, are only related to social capital in their own business and not related to social capital organized in a business group that allows collaboration. If they have a cooperative relationship between craftsmen, this will be a great strength for them in optimizing their business, both in the production process, as well as in the process of marketing their products. By cooperating in a business group, it will allow them to develop better in doing their business and they can have fairly strong bargaining power in dealing with the coconut sugar market, especially in determining the selling price of the market. If the potential of this social capital can be optimized, then it will become the internal strength of coconut sugar craftsmen in doing their business. As stated by Putnam (1995) that social capital, which consists of norms, trust, and cooperation is a picture of social organization, which can be a means for coordination and cooperation that is mutually beneficial. According to Kuncoro (2010) to see the power of social capital in supporting the achievement of organizational goals is when it interacts with the social structure. The results of this study are not in line with the results of previous studies such as Prakasa (2018), Hoq, et al. (2017), Rahajuni, et al. (2016), Felício, et al. (2014), Dai, et al. (2015), and Jalali, et al. (2013).

The human capital variable, in this case using work experience indicators, also has an insignificant negative effect on the performance of SMEs. This insignificant effect can occur related to conditions based on the results of interviews with sugar craftsmen, there are known that the majority of them run a coconut sugar business because it is hereditary and even the majority of them hope that their children can work in other fields that are considered more comfortable and provide the greater income opportunities. Due to such conditions, they become less motivated to innovate in developing their business. They run the coconut sugar business as is like what their parents did in the past. Thus, the work experience they have is not enough to encourage optimal business results, although some have received tools or technical assistance from related parties. Of course, this cannot be separated from their education level, which is mostly (89.44\%) relatively low, with formal education up to elementary school. Adequate work experience with better educational support will be able to determine one's ability to think, reason, and innovate to encourage business development. The results of this study are not in line with Badriah, et al. (2019) which state that human capital has a positive effect on productivity growth in the industrial sector.

Financial capital is the only variable that has a significant positive effect in encouraging the performance of Coconut Sugar SMEs. The regression coefficient value of 0.311025 means that holding the social and human capital constant, if financial capital increases by 1 percent led on the average to about 0.311025 percent increase the performance of Coconut Sugar SMEs in Cilongok District. The greater the capital owned, the craftsmen will have the ability to be able to have production resources independently, both coconut trees and other supporting equipment. The increasing of the performance of Coconut Sugar SMEs can happen in conditions of relatively low social and human capital when they can be independent in owning trees and providing production equipment. However, the impact of changes in business performance due to changes in financial capital is inelastic. The results of this study are in line with Badriah, et al. (2019) that capital deepening has a positive effect on productivity growth in the industrial sector and Lavado, et al. (2010) which states that innovation resulting from the support of financial capital can have a positive influence on company performance.

\section{CONCLUSIONS}

Based on the results of the analysis and discussion in this study, it can be concluded that the coconut sugar business in Cilongok District, Banyumas Regency, is not yet efficient. The performance of the coconut sugar business is influenced by financial capital. The more the financial capital of the craftsmen increases, the more their business performance will increase. While social capital and human capital have negative effects on the performance of the coconut sugar business but not significant.

Based on these conclusions, this research provides policy implications, including continuous efforts are needed from all stakeholders in assisting coconut sugar craftsmen, both from the government and the private sector, so that they can carry out the production process more efficiently and be able to produce output with better quality.

Furthermore, to optimize the role of financial capital in supporting business performance improvement, it is necessary to support the optimization of the potential of social capital and human capital through the institutionalization of social capital through the formation of business groups for coconut sugar craftsmen and optimizing the role of village governments in facilitating development and cooperation with various competent parties. 


\section{REFERENCES}

Badriah, L.S., Alisjahbana, A.A., Wibowo, K, \& Hadiyanto, F. 2019. Labour Productivity Growth in the Industrial Sector of Indonesia: Structural Bonus or Structural Burden? Malaysian Journal of Economic Studies, 56(1), 139-159.

BPS. 2019. Persentase Penduduk Miskin Menurut Kecamatan di Kabupaten Banyumas, https://Banyumaskab. bps.go.id.

BPS. 2020. Provinsi Jawa Tengah Dalam Angka (Jawa Tengah Province in Figures), https://jateng.bps.go.id.

Cooperative Service, Small and Medium Enterprises Central Java Province. 2019. Time Series Data UMKM Binaan Propinsi Jawa Tengah.

Dai, W., Mao, Z. Zhao, X., \&.Mattila, A.S. 2015. How Does Social Capital Influence the Hospitality Firm's Financial Performance? The Moderating Role of Entrepreneurial Activities. International Journal of Hospitality Management, 51, 42-55.

Felício, J.A., Cuoto, E., \& Caiado, J. 2014. Human Capital, Social Capital and Organizational Performance. Management Decision, 52(2), $350-364$.

Hoq, M.Z., Wirba, A.V., \& Baig, A. 2017. Social Capital and Small Medium Enterprise (SME) Performance: An Exploratory Study. International Journal of Novel Research in Marketing Management and Economics, 4(1), 33-39.

Jalali, Shamsodin, Dadbeh, \& Sharifi. 2013. The Role of Social Capital and Innovation in SMEs' Success: A Partial Least Squares Approach. Journal of Basic and Applied Scientific Research, 3(4), 515-522.

Kuncoro, M. 2010. Ekonomi Pembangunan: Masalah, Kebijakan, dan Politik. Jakarta: Erlangga.

Kurniati, E.D. \& Prajanti, S.D.W. 2018. Batik SMEs Efficiency and Entrepreneurship Role in Innovation. Jejak, 11(2), 377-391. DOI: https://doi.org/10.15294/jejak.v11i2.16058

Lavado, A.C. Rodriguez, G.C., Cabello, C. 2010. Social and Organizational Capital: Building the Context for Innovation. Industrial Marketing Management, 39, 681-690.

Muslihuddin, M.P., Laapo, A., Asih, D.N. 2020. Analisis Efisiensi Usaha Penangkapan Ikan dengan Menggunakan Pancing Ulur di Kecamatan Ampana Kota Kabupaten Tojo Una-Una (Input Use Efficiency Of Handline Fishery Effort In Ampana Sub-District, Tojo Una-Una District). e-J. Agrotekbis, 8(1), 71-80.

Nee, V., Liu, L., \& DellaPosta, D. 2017. The Entrepreneur's Network and Firm Performance. Sociological Science, 4, 552-579. DOI: 10.15195/v4.a23.

Nicholson, W. \& Snyder, C . 2010. Intermediate Microeconomics and its application. 11 Ed. USA: SouthWestern Cengage Learning

Prakasa, Y. 2018. Exploring The Impact Of Social Capital On Entrepreneurial Orientation And Business Performance (Study on Members of MSMEs Communities in Malang). Jurnal Profit, 12(1), 20-31.

Putnam, R.D. 1995. Tuning In, Tuning Out: The Strange Disappearance of Social Capital in America. Political Science and Politics, 28(4), 664-683.

Rahajuni, D., Badriah, L.S., Suprapto. 2016. Potensi Modal Sosial Dalam Rangka Menurunkan Tingkat Kemiskinan Pada Penerima Manfaat PNPM Mandiri Perdesaan. Prosiding Seminar Nasional \& Call paper Pengembangan Sumberdaya Perdesaan dan Kearifan Lokal Berkelanjutan VI, 24-25 November 2016.

Soekartawi. 2006. Analisis Usahatani. Jakarta: UI-Press. 